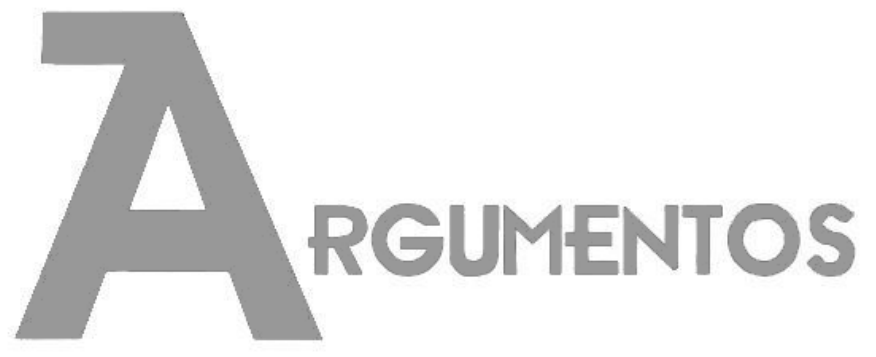

Vol. 17, n. 2, jul./dez. 2020 ISSN: 2527-2551 (online)

https://www.periodicos.unimontes.br/index.php/argumentos

\title{
Entrevista com Luis Henrique Rolim
}

Entrevistadoras:

Raquel Valente de Oliveira ${ }^{1}$

Tuany Defaveri Begossi²

Recebido em: 29/04/2020

Aprovado em: 01/06/2020

Luis Henrique Rolim possui graduação em Educação Física pela Pontifícia Universidade Católica do Rio Grande do Sul (2004), especialização em Psicomotricidade Relacional pela Universidade La Salle (2006), mestrado em Ciências do Movimento Humano pela Universidade Federal do Rio Grande do Sul (2008) e doutorado em Ciências do Esporte pela Universidade do Esporte de Colônia, Alemanha (2019). Atualmente, Rolim é professor no Curso de Educação Física na Escola de Ciências da Saúde e da Vida da Pontifícia Universidade Católica do Rio Grande do Sul, onde também atua como pesquisador no Grupo de Pesquisa em Estudos Olímpicos. Desenvolve pesquisas de cunho historiográfico, sociocultural e no âmbito dos Estudos Olímpicos, explorando os processos de construção de narrativas, identidades, representações, memória e imaginário social. Desde 2008, é membro do Comitê Brasileiro Pierre de Coubertin. Entre 2009 e 2016, foi Diretor de Pesquisa no Museu Olímpico e do Esporte em Doha, no Catar, e, desde lá, atua como consultor para o desenvolvimento de projetos museográficos e expográficos, visando o diálogo histórico-político, sociocultural e

\footnotetext{
${ }^{1}$ Doutoranda em Ciências do Movimento Humano pela Universidade Federal do Rio Grande do Sul (UFRGS), Brasil. E-mail: raquelvvallente@hotmail.com. ORCID: http://orcid.org/0000-0003-16876456.

${ }^{2}$ Doutoranda em Ciências do Movimento Humano pela Universidade Federal do Rio Grande do Sul (UFRGS), Brasil. E-mail: tuany_begossi@hotmail.com. ORCID: http://orcid.org/0000-0002-25965963.
} 
educativo entre o esporte e a sociedade. Na entrevista apresentada para o Dossiê "Jogos Olímpicos e Paralímpicos: esporte como direito de todo(a)s?", Luis Henrique Rolim fala sobre sua trajetória e a formação como pesquisador no âmbito dos Estudos Olímpicos no Brasil, explorando questões acerca de seu envolvimento com os Jogos Olímpicos, onde atuou em distintos contextos e posições. A filosofia e os valores do Olimpismo são eixos norteadores da narrativa do entrevistado, que explora o papel da história e da cultura na construção de narrativas esportivas no âmbito Olímpico. Seu relato expressa os significados e os sentidos do Movimento Olímpico para a conquista do direito das pessoas à prática esportiva. No viés de políticas públicas e de investimento financeiro ao esporte, Luis Henrique Rolim trata das interfaces: esporte de alto rendimento ou esporte para todos(as)? As narrativas do entrevistado evidenciam aspectos históricos e socioculturais do esporte Olímpico nos cenários nacional e internacional, revelando representações construídas ao longo de trajetória pessoal e profissional.

Luis Henrique, inicialmente nós agradecemos pela sua disponibilidade para conceder essa entrevista para nós e pela oportunidade de conhecermos mais sobre a sua inserção no âmbito dos Estudos Olímpicos, dos Jogos Olímpicos e demais aspectos relacionados a sua trajetória. Com relação a isso, você poderia falar sobre a sua trajetória profissional no âmbito do Esporte Olímpico e dos Jogos Olímpicos?

Eu nunca fui um atleta de alto rendimento do Movimento Olímpico. A minha trajetória é dentro do âmbito da pesquisa. Ela começou em 2002, com a fundação do Grupo de Pesquisa em Estudos Olímpicos da Pontifícia Universidade Católica do Rio Grande do Sul (PUCRS), na qual, naquele momento, eu era um estudante. A partir da participação no Fórum de Estudos Olímpicos que se realizou em 2002, no Rio de Janeiro, se constituiu esse grupo. Aquele era um período, vamos dizer assim, ainda de muita expectativa, porque o Brasil nunca tinha sediado Jogos Olímpicos. Então, de uma certa forma, algo bem distante da nossa realidade. No cenário, era uma questão mais de Jogos Sul-Americanos, que eu acho que ocorreu depois, em 2007. Então, foi esse o meu primeiro contato e, a partir daí, eu comecei a caminhar mais nessa questão dos estudos Olímpicos, na questão do Movimento Olímpico, a entender mais sobre essa área de pesquisa, de como funciona as relações também dentro do esporte no âmbito geral. 
A partir daí, então, eu comecei a direcionar a minha área de pesquisa e menos a área de atuação, porque, como eu falei, eu fiz a especialização em Psicomotricidade e eu atuava muito na escola. Mas, a área de pesquisa, eu direcionei muito para isso e com a minha entrada no mestrado na Universidade Federal do Rio Grande do Sul (UFRGS) foi quando eu consolidei essa temática como parte de uma linha de pesquisa na área mais histórica e sociocultural de estudos Olímpicos. Na verdade, os estudos Olímpicos, um parêntese aqui, é um campo muito vasto, ele engloba quase tudo, principalmente, porque quando a gente fala do Movimento Olímpico, a gente fala não só dos Jogos Olímpicos, mas sim, de toda a questão de valores no esporte, a questão da educação através do esporte.

A partir disso, eu vi várias possibilidades, mas eu acabei direcionando para aquilo que eu mais me interessava, que era sempre olhar a partir de uma perspectiva histórica, do entendimento e do desenvolvimento desse fenômeno em diferentes contextos brasileiro e a relação com o movimento no exterior - como isso foi se desenvolvendo ao longo do tempo e como isso afeta, ainda hoje, nas relações, principalmente nas representações de identidades. Então, foi por esse caminho que eu também continuei e depois fui desenvolvendo a minha carreira, não só na questão acadêmica, mas também profissional. Foi quando eu acabei recebendo o convite para ser diretor de pesquisa de um projeto, em um museu Olímpico que ia ser criado no Oriente Médio, em um país que, em 2009, se chamava Catar e que "ninguém conhecia". Hoje "todo mundo" conhece, vai ser sede da Copa do Mundo de Futebol. Mas, naquele momento, era algo bem novo para mim e eu acabei tendo esse convite por causa desse envolvimento com a área de estudos.

Também, em 2008, foi quando o Comitê Olímpico Pierre de Coubertin - que é, vamos dizer assim, o fundador dos Jogos Olímpicos, do Movimento Olímpico moderno - cria um comitê internacional. Já existiam os comitês nacionais. Então, no ano de 2008, ocorreu a transferência da sede do Comitê Brasileiro Pierre de Coubertin para a PUCRS. $E$, nesse movimento foi quando eu conheci outras pessoas que estavam envolvidas também com o Comitê Olímpico Pierre de Coubertin e que foi de onde partiu esse convite para eu fazer parte desse projeto do Museu Olímpico do Catar. Foi então que eu comecei realmente, vamos dizer assim, a viver o Movimento Olímpico de outra forma, de uma forma mais globalizada, entendendo as relações e como isso afeta 
diferentes contextos, em diferentes culturas. Aa partir daí, eu tive uma perspectiva mais, vamos dizer assim, de mundo, de como o Movimento Olímpico funciona, e, desde lá, eu continuei trabalhando nessa questão do Movimento Olímpico em si e de como [...]. Porque também teve esse movimento na minha carreira, da questão de como voltar a trazer as questões dos estudos Olímpicos para cá a partir da minha volta ao Brasil. Qual seria essa contribuição? Então, quando eu comecei a participar desse mundo, que trabalha com cultura, que trabalha com narrativas, com interpretações, que é o mundo dos museus e exposições, eu comecei a entender que a minha área de atuação poderia não ser só através da pesquisa, mas, também, a de educar através disso. Então, foi sempre um viés que eu nunca deixei, mesmo me tornando profissional dessa área, sempre nas minhas relações, a minha formação de educador estava sempre presente. Mas, eu tinha sempre um pouco de ansiedade na área acadêmica, de estar sempre falando para as mesmas pessoas, de estar sempre me comunicando com os acadêmicos e aquilo acaba se tornando somente um movimento de uma bolha, que não realmente atinge a pessoa que deveria atingir.

Através dessa questão, da museografia, foi quando eu comecei a entender que eu realmente poderia me comunicar com as pessoas, com os atores, com as pessoas que fazem parte desse movimento de uma forma mais efetiva e de também educar as questões de valores através disso. Então, me comunicar de diferentes formas, não só através da questão de escrita de artigo acadêmico, mas também da criação de um blog, de uma rede social, criar outras perspectivas de trazer o conhecimento para as pessoas que realmente deveriam estar atuando. Nesse sentido, também entra muito essa questão da atuação do Comitê Pierre de Coubertin que trabalha com agentes sociais.

Eu acho que esse movimento de ser acadêmico, mas também ser educador, de trabalhar com as pessoas ou profissional, foi muito importante para mim, porque eu tinha essa ansiedade, do ser acadêmico que acabava sendo uma pessoa isolada do mundo. Eu sempre quiz formar opinião, mas, também, ter o pé no mundo, não só na criação do conhecimento em si. Então, esse movimento foi muito importante para mim e, agora, no meu retorno ao Brasil, que aconteceu no ano retrasado, no final de 2018 , foi essa a ideia de que, ao retornar ao Brasil, eu gostaria de trazer toda essa bagagem de desenvolvimento da cultura, do esporte, do Movimento Olímpico para cá. 
Vocês sabem, também trabalham nisso, o quanto ainda é sub explorado o potencial de se ensinar através de exemplos do passado e como é importante isso na questão de criação de identidade, de fortalecimento de representatividades. Então, eu acho que esse é o movimento que eu busco, desde a minha volta, e é um movimento que eu quero continuar aqui, não só como linha de pesquisa, mas, principalmente, como linha de atuação. Trazer, por exemplo, os protagonistas para perto das pessoas, eles contarem as histórias para as pessoas reconhecerem quem são, para que a comunidade dê valor àquilo que hoje se constitui como o Movimento Olímpico através dessas histórias e do esporte em geral.

Acho que a gente carece ainda muito de dar valor a nossa cultura. A gente sempre fica olhando a cultura a partir de uma perspectiva de fora e tenta importar as coisas. Na verdade, a gente tem que ter esse olhar de fora, como eu tive e tenho, mas, ao mesmo tempo, nós precisamos ter a capacidade de entender os contextos e de fazer isso dentro da nossa realidade. Aqui, eu não estou falando só da questão financeira, estou falando da questão também de entendimento de quem nós somos. Se o esporte brasileiro e o Olímpico têm esse formato, essa identidade, é porque se trabalhou até hoje isso e talvez a gente possa comunicar ele de diferentes formas.

Acaba aparecendo muito "o esporte de alto rendimento, são os atletas Olímpicos", ficam como mais uma entidade, não só, vamos dizer assim, pessoas que [...]. As pessoas olham muitos os resultados, não o processo. O processo de ser atleta Olímpico não é nada glamouroso como as pessoas, às vezes, pensam. Os que aparecem são a ponta do iceberg. Existe um universo para que as pessoas entendam que no ser atleta existem várias outras coisas interessantes e importantes, mas, também, existem vários outros sacrifícios, outras escolhas. Eu acho que esse lado humano está sempre presente e ele precisa ser explorado, porque é assim que nós nos conectamos, que nós nos entendemos, que a gente se identifica como gaúcho, brasileiro, enfim. Então, eu acho que esse é um desafio que eu lanço e que eu trago para minha atuação.

Luis, comente sobre políticas públicas e investimento financeiro nas interfaces "esporte de alto rendimento e esporte para todos(as)". 
Esse é um tema bem amplo e eu vou pegar através da perspectiva de ciclos Olímpicos. O que acontece? O Brasil, como eu falei lá no início, quando eu comecei a estudar isso, em 2002, a perspectiva de ter um ciclo Olímpico, de ter os Jogos no Brasil era quase remota. Existiam algumas possibilidades, alguns investimentos que tinham sido feitos, algumas tentativas já tinham sido feitas de trazer os Jogos. Claro, isso depende de um movimento bem generalizado e aqui eu não quero entrar na questão de tudo que a gente sabe, de tudo que foi envolvido, nas questões de corrupção que já foram explorados, já são sabidas de todos do que foi o processo de vinda dos Jogos Olímpicos para o Brasil.

Então, eu quero olhar a partir da perspectiva de, sim, houve corrupção, sim, houve gasto de dinheiro público excessivo para a realização de um evento, mas, sim, também houve benefícios para as pessoas. Então, existe um legado. É aquela história que a gente precisa tirar a água suja da banheira, mas não o bebê inteiro. Então, eu quero olhar a partir desse aspecto de como é importante a vinda desse evento, e aí entra muito essa questão das políticas públicas para o desenvolvimento do esporte em si. Ele é positivo, mas ele também tem um lado muito negativo, porque, normalmente, eu vejo que no Brasil o imediatismo sempre é predominante, ou seja, pelo fato de se ter o evento, se tem o investimento e é efêmero, ele é pontual.

Hoje, talvez, a gente possa pensar que todo investimento que foi feito para os Jogos, com os atletas, não era sustentável. Hoje fica claro isso. A gente sabe que o estado do Rio de Janeiro paga as consequências disso. A gente vê que quase todos os governadores e pessoas que estavam envolvidas estão hoje na cadeia. Então, os Jogos mostram o lado bom e o lado ruim do ser humano. Talvez, se não tivesse tido os Jogos, essas pessoas ainda estariam dirigindo ou se beneficiando do dinheiro público. Elas se beneficiaram, então, elas devem pagar por isso agora.

Mas, então, o que acontece? No esporte de alto rendimento, o investimento em políticas foi muito nesse sentido, não sustentável a longo prazo, mas, sim, para que se tivesse uma representatividade do Brasil no quadro de medalhas. Eu acho que a função do Comitê Olímpico Brasileiro, nesse caso, não é só no esporte de alto rendimento para se fazer presente no quadro de medalhas com uma boa representatividade. Eu, particularmente, acredito que o número de medalhas não representa em nada o desenvolvimento do esporte do país. Aliás, o quadro de medalhas nem é reconhecido 
pelo Comitê Olímpico Internacional, porque os Jogos Olímpicos, em teoria, são os Jogos entre atletas e não entre países. Então, saber se o Brasil ficou em 10ㅇ ou em 20ㅇ não faz nenhuma diferença, porque não deveria representar o quanto esse país é melhor do que o outro. Isso foi uma invenção. Como a gente é historiador, a gente sabe disso, uma invenção que foi feita pelos meios de comunicação. Foi a criação de rivalidades, principalmente, na questão da Guerra Fria um tempo atrás - Estados Unidos, União Soviética, para quem era uma potência Olímpica. Hoje, a gente também sabe o quanto a Rússia escondia esquemas de doping, que era financiado pelo governo para que tivesse também uma representatividade.

Se a gente olhar por esse prisma global, os Jogos é o evento, mas, de um movimento que deveria ser muito maior que o evento. $O$ evento é o produto mais caro, que vende e que tem investimento. Ali ele traz o lado bom e o lado ruim do ser humano. E aí, nesse sentido, as políticas públicas, com relação ao Brasil e do mundo, com relação aos Jogos, é pautada muito nisso: quais são os atletas que vão trazer medalhas e que vão representar o país de uma forma, vamos dizer assim, de uma representatividade de ser campeão, de ser medalhista? Principalmente, nessa ideia que a gente tem aqui de se associar a algo positivo. Então, se eu sou vencedor, eu me identifico como vencedor e eu preciso ter isso.

Eu acho que a lógica está muito pautada nessa nossa ideia de identidade, que é: eu preciso me associar a algo vencedor, mas, não a algo que está sendo desenvolvido. A gente tem pouca paciência, a gente quer o resultado, a gente precisa do resultado, a gente precisa ser campeão. Existe sempre uma ansiedade muito grande que é refletida nas políticas públicas e é da nossa cultura. É uma cultura do imediatismo, é uma cultura do agora, do herói, ou seja, do gestor público - e essa palavra aqui seria o ideal, do "gestor público", às vezes, de gestão não tem nada. O ideal seria um planejamento a longo prazo e uma continuidade com outras gestões. Que se construa políticas mais eficazes, mais eficientes que realmente criem uma base de atletas, de uma população que fique mais saudável, que impactem menos no Sistema Público de Saúde e que, lá na ponta dessa pirâmide, iriam sair atletas de alto rendimento. Mas, não! A pirâmide é invertida. A gente pensa a partir do investimento na pessoa de cima para se chegar embaixo, que a partir do exemplo daquela pessoa no topo, isso vai gerar um evento cascata e que as pessoas vão praticar mais esporte. 
Por exemplo, a gente precisa que se tenha um Gustavo Kuerten para que as pessoas pratiquem tênis. Sim, nós precisamos ter o Gustavo Kuerten para que as pessoas também tenham um exemplo, mas, uma política pública não deveria ser pautada em uma pessoa ou em um esporte, ela deveria ser pensada em uma questão ampla. Aqui, também, eu faço uma ressalva de que eu não sou especialista em políticas públicas, mas, essa é a minha visão, a partir do viés cultural de como as políticas públicas são tratadas. Eu acho que reflete muito nessa questão do ser herói do brasileiro, que nós precisamos do mártir, "eu fui a pessoa que fiz isso", eu e eu. Então, é muito difícil de ver um movimento contínuo, de ver um movimento de desenvolvimento de políticas que são a longo prazo, porque as pessoas querem deixar a marca delas. Elas querem ser o pai da criança e com isso acaba que nós temos processos quebrados.

A gente pode pegar o exemplo do Maracanã. O Maracanã, para dois grandes eventos, teve duas grandes reformas no período de dois anos. É óbvio que não iria dar certo, é óbvio que teve gasto de dinheiro a mais do que o necessário. Então, o local foi sede em 2014 para a Copa do Mundo de Futebol e, em 2016, para os Jogos Olímpicos, mas, para a Copa do Mundo, teve de fazer uma reforma e depois teve de fazer outra reforma para os Jogos Olímpicos. Então, a máquina de gasto do dinheiro público está sempre presente. Eu acho que o que não falta são possibilidades e isso é sistêmico, é da nossa cultura. Eu falo isso porque vivi muito tempo em outra cultura. Então, existem outros desafios em outra cultura e existem outras possibilidades. Aqui, nós somos assim.

Uma forma de mudar isso seria através de leis mais rígidas. As nossas leis são rígidas, mas, existe sempre formas de passar por cima dessas leis, porque nós somos assim. Nós sempre pensamos em uma forma, porque, aqui, desde sempre, há a ideia de que a gente precisa tirar vantagem de algo. Então, se viu também os jogos como uma oportunidade de tirar vantagem e poderia ser uma vantagem para muito mais pessoas, não só para poucas pessoas. E isso afeta não só o esporte de alto rendimento, mas o esporte para todos.

O esporte adaptado serviu para criar suas próprias analogias e, dentro disso, fora do holofote. De uma certa forma, ficou mais viável de se consolidar o movimento, vamos dizer assim, mais forte nas questões de políticas públicas, porque, agora que as pessoas estão se voltando para isso, agora que os empresários querem investir nisso. Mas, por quê? Porque agora esse movimento está mais consolidado, ele está mais estabilizado, 
as pessoas sabem o que elas querem, ele já está enraizado de forma diferente. Eu vejo o esporte adaptado e o Movimento Paralímpico, por exemplo, muito mais seguro na questão do desenvolvimento humano a longo prazo. Eu acho que comparar os dois é difícil, mas um sempre teve o holofote e quando a gente tem muito o holofote, tem muito dinheiro envolvido, isso é muito mais complexo. O outro teve mais tempo de ser baseado em políticas mais concretas, em um viés educacional, em um viés de inclusão, do que o outro. Então, eu o vejo bem mais enraizado em políticas, mais reais, que vão tocar mais a sociedade.

Mas, claro, esse é um tópico muito amplo e a gente poderia falar de iniciativa privada, da importância disso, da importância da relação com o governo federal, as dificuldades que nós temos com os três tipos de poder (federal, estadual e municipal), da distribuição do dinheiro, do dinheiro não sair e ir através do Comitê e ser repassado. Então, eu acho que é um tema muito complexo e eu também não tenho todos os argumentos para falar sobre ele. Por isso, eu preferi entrar mais nessa questão, de talvez como a nossa cultura influência no desenvolvimento das políticas públicas no Brasil.

De que forma você observa os valores do Olimpismo em contexto de alto rendimento e/ou em outros espaços esportivos nos tempos passado e presente?

Bom, vamos conceituar aqui. Como eu falei, o Movimento Olímpico é maior que os Jogos Olímpicos, na minha concepção. O que aparece mais é um evento de 15 dias, porque ele tem mais investimento, mas, ele não deveria ser uma expressão maior desse Movimento Olímpico. O Movimento Olímpico é o desenvolvimento humano através do esporte, educação por valores, a famosa educação Olímpica. Educar as pessoas através do esporte, é assim que eu penso. Então, o Movimento Olímpico deveria ser a base dos Jogos Olímpicos, só que se a gente pensar em história e, ao longo do desenvolvimento dele, os Jogos Olímpicos não são desassociados do desenvolvimento da humanidade, da história, dos eventos sociais, contextos em que ele foi envolvido. Por exemplo, agora, só para a gente ser pontual, já que a gente está aqui no dia de hoje, nós não sabemos se nós vamos ter os Jogos Olímpicos em Tóquio por causa de uma epidemia de um vírus. Seria a primeira vez na história que os Jogos não iriam acontecer, não por causa da guerra, mas por causa de uma epidemia. 
Então, os Jogos não são desassociados na realidade ou essa questão de autonomia do esporte, que algumas pessoas pregam. E, até o próprio Movimento Olímpico diz que deve ser desassociado de questões políticas, de questões religiosas. Por fundamento acadêmico, eu não consigo perceber dessa forma. Se o Movimento Olímpico é o que é hoje e os Jogos é o que é hoje, é porque o contexto histórico de diferentes momentos constituiu ele e não ao contrário. Talvez, em algum momento, eles expressaram outras coisas e influenciaram outras coisas. Então, as questões dos valores nos Jogos em si, como eu falei, os Jogos trazem o melhor e o pior do ser humano. Assim como nós vamos ter exemplos maravilhosos, nós vamos ter exemplos horríveis, porque ele é uma festividade humana, uma festividade social, cultural. Como qualquer festividade humana, social e cultural, traz o lado bom e o lado ruim do ser humano. Mas, qual é o lado bom e o lado ruim do ser humano? Depende da perspectiva que tu olhas, pode ser ruim para mim, mas pode ser bom para ti. Então, ele é uma expressão multicultural.

As pessoas não entendem, talvez, o porquê de o muçulmano querer competir, a mulher querer competir com véu. Que ela tenha a escolha se ela quer ou não, não que uma regra determine a forma como ela vai competir. Ou a jogadora de vôlei de praia, que ela tenha que, obrigatoriamente, competir de biquíni, ela não pode escolher isso. Então, eu acho que nisso, os Jogos Olímpicos ainda são muito enraizados em ideias do século XIX, que foi quando ele nasceu. Então, a gente precisa entender isso. Se a gente for pensar que o Pierre de Coubertin falou que as mulheres não deveriam fazer parte dos Jogos Olímpicos [...]. Sim, mas, nós estamos falando do século XIX e início do século $X X$, o contexto era diferente. Hoje, isso é inaceitável e os Jogos Olímpicos foram sendo adaptados por tudo isso, por essa influência do desenvolvimento de tecnologias, do desenvolvimento do nosso entendimento enquanto humanidade.

Como iríamos prever que nós teríamos uma guerra na Síria ou, por exemplo, os atletas Russos que agora não vão poder competir por algo que foi feito lá atrás? E o Movimento Olímpico tem que decidir agora se eles vão ser parte ou não vão ser parte. A guerra na Síria, os atletas sírios, enfim, eles têm que fazer parte ou não tem que fazer parte porque eles não têm um país. Então, eu acho que os Jogos Olímpicos são essa expressão cultural além do recorde, além da performance física, para além disso. Eu sempre vou olhar por esse ângulo. Se eu fosse, talvez, um treinador, uma pessoa da 
preparação física, eu iria sempre olhar por uma perspectiva da performance, do quanto os Jogos Olímpicos, principalmente, as disciplinas, os esportes mães, por exemplo o atletismo, quem vai ser a pessoa mais rápida do mundo. Mas, eu sempre olhei por esse lado cultural dos Jogos, o esporte como uma expressão cultural, como uma prática cultural. Então, os Jogos é um evento que celebra isso.

Eu acho muito válido salutar que ele ainda é conectado, porque a diferença dos Jogos Olímpicos, o porquê de ele não é só um campeonato mundial, é justamente por causa disso, porque ele ainda traz ritos e cerimônias que remetem a algo que é transcendente a nós enquanto ser humano. Nós precisamos de ritos de passagem e os Jogos Olímpicos é um rito de passagem para um atleta. Ele é um rito de passagem para as pessoas que estão envolvidas nele. Participar disso é um rito de passagem. Então, assim como era na antiguidade, que os gregos se encontravam de quatro em quatro anos e era uma forma de pensar o tempo, para os atletas isso é uma forma de pensar o tempo também. Eles treinam dentro de um ciclo Olímpico, eles vivem em um ciclo Olímpico e as pessoas que fazem parte disso, pensam isso também.

Ao mesmo tempo em que existe o movimento de fora para com essa prática e ela absorve as questões de contextos temporais, a gente sempre tem que pensar que o Movimento Olímpico e os Jogos quase nunca são proativos. Eles são sempre, vamos dizer assim, absorvendo o movimento da temporalidade, do contexto onde se vive. Como estou dizendo, a questão das mulheres, a questão do doping. Então, ele está sempre um passo atrás, porque justamente isso, ele é uma expressão maior. Se hoje se fala que os Jogos vão ter a maior representatividade em termos de igualdade entre homens e mulheres é porque isso vem se construindo ao longo do tempo. Ele não nasceu como Jogos para mulheres. Existiu disciplinas, ou existem ainda, que eram só para homens, então nunca que iria ter uma igualdade. Mas, a partir de 2012, as mulheres poderiam começar a praticar o boxe Olímpico, ter uma atleta Olímpica.

A última nação, vamos dizer assim, que mandou atletas mulheres foi a Arábia Saudita, em 2012. Talvez, de uma forma mais representativa (não foi uma efetiva participação), mas, é um movimento dos Jogos para com aquela sociedade que tem os seus valores, que tem a sua cultura. Então, ele é esse local do conflito de identidades, disso que a gente estuda, do embate de representações. Ele acontece ali, as pessoas estão ali, as pessoas são diferentes. Eu acho que essa celebração, enquanto humanidade 
que emerge todos os valores, é realmente a utopia do Movimento Olímpico e dos Jogos Olímpicos, de que as pessoas se entendam através disso. É uma linguagem universal e eu acho que é importante a gente ter essa utopia, apesar de eu acreditar que ela nunca vai existir. Mas, se a gente não tem essa utopia, a gente nunca vai buscar ela, então a gente desiste já desse sonho.

Eu acho que os Jogos sempre vão trazer esses elementos para reforçar essa narrativa de esperança, de ideal, seja através de um exemplo pontual, seja através de uma participação, não só de uma vitória, mas, de uma participação. Eu acho que como prática cultural, ele sempre vai remeter a isso e o Movimento Olímpico faz muito bem sempre em reforçar isso, em deixar isso claro. Claro, talvez, em uma forma de marketing, de dar valor ao seu produto, mas, é uma forma de dizer "olha, ainda há esperança, já existe um movimento de igualdade, de direito, já existe o movimento". Bom, daí agora você pode me questionar: agora vamos proibir os atletas de fazerem manifestações durante os jogos? Aí entra todo o conflito que eu disse, de trazer o bom e o ruim junto. É a questão de que, ao final das contas, ele é um produto e existem pessoas que colocam dinheiro e elas não querem relacionar a marca delas a certos tipos de comportamentos. Esse é o preço que se tem para que ele seja um evento dessa magnitude. Então, nem tanto o céu, nem tanto a terra, com os Jogos Olímpicos.

Eu sempre olho ele a partir desse prisma mais crítico. Não de abominar ele como coisa totalmente desprezível e não também só a melhor coisa do mundo, mas como uma prática humana, social, cultural. Como qualquer uma tem os seus defeitos, mas, que persiste. Então, se ela persiste por mais de 100 anos é porque ela tem elementos de valores que são importantes, que as pessoas ainda acreditam naquilo. Eu acho que isso é o importante de sempre ser preservado. Eu acho que esse é o papel do Movimento Olímpico, sempre preservar isso e que a gente não perca essa esperança. Eu acho que é assim que a gente desenvolve as questões de valores dentro desse contexto.

Luis, você já trouxe alguns aspectos ao longo da sua fala, mas você poderia comentar um pouco mais sobre o Movimento Olímpico e o direito das pessoas à prática esportiva? 
A gente pode partir do princípio que é um direito fundamental o acesso à prática de uma atividade física. Eu não sei em qual carta que está isso, mas, é um direito universal. Então, se a gente for olhar na questão do estatuto, o ECA (Estatuto da Criança e do Adolescente), é direito da criança, é direito do adolescente, é direito do adulto, é direito do idoso, é direito de qualquer pessoa ter acesso a isso. Eu acho que como Movimento Olímpico - e não só como Jogos Olímpicos - abraça qualquer um desses públicos. Ah, mas como assim? E o idoso ou esporte adaptado? Não! Na verdade, ele trabalha com questões de valores. Quanto mais o Movimento Olímpico continuar sendo uma expressão aberta de desenvolvimento de valores, mais ele contribui para o desenvolvimento do esporte para todos. É claro que existe essa conexão do Movimento Olímpico direto com os Jogos Olímpicos e eu acho que essa é uma discussão que quem trabalha e estuda nessa área sempre deve trazer.

Vamos fazer um parêntese aqui. É aquilo que eu falei anteriormente, que são os acadêmicos falando para os acadêmicos. Enquanto os acadêmicos continuarem falando para os acadêmicos, as pessoas não vão entender o real potencial do Movimento Olímpico. É preciso que haja outras iniciativas do Movimento Olímpico (e elas existem). Talvez, no Brasil, sejam diminutas, mas, mundialmente existem para que as pessoas entendam o potencial que o Movimento Olímpico tem, para que as pessoas tenham mais acesso ao esporte. Vou trazer o exemplo do Comitê Pierre de Coubertin, que tem o apoio do Comitê Olímpico Internacional e do Comitê Pierre de Coubertin Internacional. Através dessa rede, o Comitê, hoje, apoia escolas públicas, a criação de escolas na formação através de valores, de inclusão, do esporte para todos, de projetos sociais. Então, ele fundamenta esses projetos. Ele não só dá possibilidade dessas crianças terem uma outra perspectiva de, por exemplo, participarem de algo no movimento mais internacional.

É isso que eu digo da questão dos Jogos Olímpicos para os atletas. Desse evento ser essa expressão do Movimento Olímpico apoiado por instituições e iniciativas. Elas dão essa perspectiva de possibilidades maiores do que aquela realidade. Quando a gente fala em Movimento Olímpico - eu acho que a gente pode usar essas palavras mais no entendimento de um movimento, de algo maior do que só o esporte local - é algo Olímpico. Sempre quando a gente fala em algo "Olímpico", a gente remete a algo maior, algo que engloba vários aspectos, principalmente, na questão da formação integral do 
ser humano. Não só nas questões físicas, mas, também, na questão de atitude, de valores, de ser uma pessoa melhor. Acho que essa é a contribuição que o Movimento Olímpico deve trazer sempre para qualquer iniciativa.

Por exemplo, seria também o papel do Comitê Olímpico Brasileiro, mas eu falo do Comitê Pierre de Coubertin porque é onde eu atuo. Lá, é o papel dele de instrumentalizar, de dar esse apoio a essas iniciativas para que elas possam florescer e realmente atuarem de uma forma mais efetiva. Que elas tenham visibilidade, porque, às vezes, é isso que falta para uma iniciativa, que simplesmente tenha visibilidade. Não é o apoio financeiro.

Se lembra que a gente falou das questões das políticas públicas? Não é despejar dinheiro em um projeto. É simplesmente dar a visibilidade, dar possibilidade de instrumentalizar, de capacitar as pessoas. Quanto mais o Movimento Olímpico atuar de forma descentralizada, através de iniciativas que não remetam somente ao esporte de alto rendimento, mais ele vai contribuir na questão de inclusão do esporte para todos. Então, eu acho, que nisso ele é fundamental. Eu realmente acredito no potencial.

Mas, claro, existem os desafios inerentes de cada local, inerentes de cada contexto e inerentes do esporte em si. A gente vive uma monocultura no Brasil. Quem não gosta de futebol está fora. Então, o futebol deveria, talvez, ser explorado de uma forma mais ampla. Eu vejo o futebol como o carnaval. É uma expressão da nossa cultura. Hoje, o carnaval de Porto Alegre - não os blocos de rua, mas, o carnaval, as pessoas que vivem o carnaval - está menor do que já foi. Uma expressão cultural que vem diminuindo. E o futebol nunca vai ser diminuído, porque existe sempre o investimento. Mas, aí o futebol se tornou raso nesse sentido. Ficou algo que é, ao mesmo tempo, acessível para todos e totalmente exclusivo para outras coisas, e sem fundamentos, sem valores, sem propósito, às vezes. Simplesmente por exaltar algo que nem as pessoas sabem mais o que elas estão exaltando, exaltar a rivalidade "Grenal".

Por que a gente exalta a rivalidade? Quando a gente fala nesse sentido dos clubes, da importância que eles deveriam ter para a educação, não só para ganhar, mas para educar, também o seu torcedor, porque no final das contas, "os torcedores" são um pai, uma mãe, uma criança. Eu levo a minha filha no estádio. A gente chega no estádio e a pessoa está exaltada do lado. O que a minha filha vai pensar? Agora a gente precisa criar uma linha especial para mulheres andarem de ônibus para irem até o 
estádio. Por quê? Porque elas não conseguem ir? As mulheres querem ir para o estádio. Mas, as mulheres podem ir para o estádio, isso é o que os governantes iriam dizer, mas elas podem ir, é para qualquer um. Não! Não é para qualquer um. Por que a gente tem que pensar nas especificidades de cada pessoa? De um cadeirante, de uma mulher, da criança, do idoso. Então, o futebol seria muito melhor se ele tivesse uma expressão Olímpica, que tivesse mais fundamentos que não só o dinheiro, a esperança da criança em ser um jogador de futebol para que ela conquiste algo na vida. Não é só no futebol. É em qualquer esporte.

É fundamental de qualquer esporte o porquê ser um fenômeno cultural tão forte. Ele traz algo que a gente, por meio da educação, talvez, veja isso a longo prazo: a questão da mobilidade social. O esporte é capaz de fazer a mobilidade social da pessoa, da pobreza para riqueza. E aí se lembra a questão da cultura? A nossa cultura é assim. A gente não quer construir isso. A gente não tem a paciência. A gente quer pelo talento, pelo imediato. Então, eu vou descobrir um talento. Eu sou empresário, eu descubro aquele talento e isso vai me salvar e salvar ele. Porque o processo formativo e educacional é lento e é difícil. A gente não tem elementos tangíveis para chegar a um investidor e dizer: investe nesse projeto, vai dar retorno. O investidor, no mundo real, vai olhar e dizer: mas, aonde que é o retorno? Quando? Daqui 30 anos? Daqui 30 anos eu não sei se a minha empresa vai existir. Eu quero agora. Eu quero divulgar a minha marca, o que você vai expor.

As relações são muito complexas no mercado do esporte. Por isso que a gente tem que apoiar sempre a parte educativa do esporte. Se cada uma dessas iniciativas que visam o lucro mercadológico, que movimentam o esporte, incluíssem elementos educacionais, já seria um grande avanço para o entendimento das pessoas. É o que, às vezes, está na questão do retorno desses atletas que ganham a vida, que viram ícones e depois criam projeto social. Eles querem dar um retorno, porque eles sabem da importância. Mas, fundamentado em quê? O ídolo, na expectativa de ser esse ídolo de novo. Então, quando o gestor público vê: como eu vou investir? Ele investe na pirâmide invertida de novo. Cadê o ídolo para que essas pessoas queiram ser o ídolo? E o processo formativo de educação através do esporte não é só para formar atletas, ele é para formar pessoas, melhores cidadãos, pessoas que tenham mais empatia, que a gente 
tenha uma sociedade melhor. É muito difícil a gente convencer o investidor a investir na educação, porque ela não tem esses elementos concretos.

Um projeto que é bem interessante é a Fundação Tênis, apoiada pelo Comitê Pierre de Coubertin. Eles criaram indicadores para mostrar: olha, não saiu nenhum Gustavo Kuerten daqui, mas essa pessoa está trabalhando nesse lugar, essa pessoa está fazendo isso aqui. Têm alunos que passaram pelo projeto e agora são professores no projeto. Então, isso são formas de quantificar o resultado educativo do processo formativo para que as pessoas entendam a importância dele. Que isso associe valor a uma marca, porque, no final das contas, é isso que o mercado quer. A marca se associa a um valor.

Então, com certeza, as marcas que são hoje do Ronaldinho Gaúcho não estão nada felizes com o Ronaldinho Gaúcho, porque associa a marca de uma pessoa que não tem uma identidade. Então, no final das contas, é só pelo dinheiro? Porque eu tenho certeza que ele é milionário e que a quinta geração dele não vai ter nenhum problema. Mas, e a imagem? Mas, e os processos de educação? Então, eu acho que o esporte é esse fenômeno cultural que depende muito ainda de quem está por trás dele e, às vezes, as pessoas que estão por trás dele não visualizam o potencial que ele tem, como propositalmente diminuem o potencial dele para o seu benefício próprio.

Acho bem complexo todas essas relações do esporte, da forma como ele pode ser melhor, mais inclusivo para todos. Potencial ele tem e é por isso que nós todos trabalhamos com o esporte. Mas, é muito difícil, às vezes, a gente sair desse ambiente que ele faz parte também, porque, historicamente é assim que ele se constitui. A gente sabe que para mudar práticas é preciso um movimento de ruptura muito grande. Eu acho que, por exemplo, o futebol, que faz parte do Movimento Olímpico, o esporte futebol, de tão grande que ele se tornou, ele saiu, ele tem vida própria, vamos dizer assim. Ele já está enraizado em certos elementos.

A minha perspectiva, por exemplo, agora de retorno, era isso, de trabalhar com clubes, de trazer através da parte cultural. É preciso que gente desenvolva também processos educativos com o torcedor, porque, no final das contas, o que o clube quer é que tenha uma fidelidade do torcedor. Que ele não só associe e invista no clube, seja sócio do clube, porque o clube ganha. Mas, no final das contas, essa é a mensagem que é passada: eu só faço parte disso quando eu sou vencedor. Mas, na vida, a gente não é 
só vencedor, a gente perde, ganha e a gente continua. Ser de um clube é muito mais do que ser vencedor, porque é esporte. Têm outros elementos, têm outras questões de identidade.

Acho que o Movimento Olímpico tem essa identidade mais presente, só que aí o desafio é enfrentar a monocultura do futebol. O futebol tem o potencial, mas ele não trabalha muito essas questões de mudança de paradigma através disso. Existem algumas iniciativas bem interessantes. Por exemplo, agora, o quanto os clubes têm mais responsabilidade social, são mais engajadas em algumas campanhas, já existe um movimento. A mulher consegue frequentar mais o estádio, mas o estádio também virou menos popular, ficou mais elitizado. Então, é difícil. A balança sempre pesa para um lado ou para o outro. A gente poderia ficar a tarde inteira falando sobre isso, mas eu acho que é isso.

Gostarias de destacar algo? Algo que a gente não tenha contemplado nas questões? Ou, alguma mensagem que tu queiras deixar para nós finalizarmos a entrevista?

Eu já deixei várias mensagens, não tem uma mensagem final. Não sou uma pessoa de grandes frases no final. Mas, pessoalmente, primeiro agradecer pela oportunidade de ser escolhido dentre tantas pessoas que poderiam ser escolhidas. Realmente, eu agradeço pela escolha de todos vocês.

Eu acho que se a gente pensar no tema dessa entrevista, se a gente pensar nas questões mais amplas do esporte, ainda existe muito espaço para o Movimento Olímpico se tornar enraizado em nosso país. A gente estava falando antes, por exemplo, se a gente vai para uma outra região, Amazônia, Manaus, enfim, é um outro Brasil. 0 Brasil ainda tem o potencial muito grande, não só na questão de captação de talentos, mas, muito de usar o potencial do esporte para o desenvolvimento humano e ser mais inclusivo. Que as políticas públicas pensem nesse potencial, não só no retorno do rendimento esportivo. Eu acho que a ideia central é que quanto mais a gente levar os processos educativos para as políticas públicas do esporte, mais nós vamos entender o potencial que ele tem de mudança na nossa realidade. 
Eu acho que esse seria o ideal que a gente deveria buscar. Trazer os valores para as pessoas, não em forma de marketing ou de campanha política, mas realmente de desenvolvimento humano e pensando em toda a questão do impacto que tem a prática, a atividade física para a nossa sociedade, para uma sociedade mais ativa, mais sadia, mais inclusiva, mais empática. Então, eu acho que a gente precisa disso urgentemente e o esporte é a ferramenta. Ele é uma ferramenta importante. A gente deveria pensar muito nisso, cada um em suas áreas de atuação. Eu não sou um gestor público, trabalho na área da cultura, do esporte. Então, eu penso nisso, trazer o potencial do esporte para o desenvolvimento mais educativo, para o desenvolvimento das pessoas.

Sempre vai ter o lado comercial, sempre vai ter um investidor querendo saber onde ele vai lucrar, porque é assim que funciona também. A gente vive nesse contexto, mas, existe espaço também para a gente incluir outros elementos formativos, de valores. Eu acho que esse movimento existe, mas, ainda, ele é muito pequeno. Ele tem um potencial muito grande no Brasil para desenvolver isso, com pequenas iniciativas, não só em escalas nacionais. Eu acho que isso também é importante, deixar claro, que quando eu falo nesse sentido, não é pensar em uma política nacional somente, mas, também, em uma política local, uma política que seja bem localizada.

Como eu dei o exemplo do esporte adaptado, que entenda bem as dificuldades, do que é preciso ser feito. A partir daí fica mais fácil de se desenvolver de baixo para cima e não só de cima para baixo. Então, políticas que vejam as atividades de pessoas que desenvolvem projetos interessantes para o desenvolvimento humano através do esporte. Elas deveriam receber esse apoio para que isso possa, depois, ser replicado de uma forma de baixo para cima. Inverter essa pirâmide. Ela precisa ter uma base mais sólida. Então, acho que esse seria o recado final.

Luis Henrique, em nome do grupo de pesquisa Núcleo de Estudos em História e Memória do Esporte e da Educação Física (NEHME), em nome do Centro de Memória do Esporte (CEME) e em nome da Professora Doutora Janice Zarpellon Mazo, nós agradecemos muito pela entrevista. Foi uma satisfação ouvir a sua fala e aprendermos muito através dela. Muito Obrigada!

Obrigado. Eu que agradeço. 